\title{
Functions And Meanings Of Indonesian Patriotic Songs
}

\author{
By: Wisnu Mintargo \\ Lecturer, Surakarta Indonesian Institute of Arts \\ Email : wis_num@yahoo.com.sg
}

\begin{abstract}
This study aims to identify functions and meanings of patriotic songs as part of the preservation and character education system so that younger generation can understand through songs. A number of qualitative data were collected and then presented in an article. The primary function of the song "Bagimu Neg'ri" has the meaning of nationalism which is used as a device in a ceremony, or known as Magnetic Song. The secondary function of the song "Maju Tak Gentar" is known as Rhetoric Song, which contains a message of patriotism. Keywords: Patriotic Songs, Functions and Meanings
\end{abstract}

\section{INTRODUCTION BACKGROUND}

Indonesian patriotic songs or national songs are called functional music. In patriotic songs, the most important things are lyric and melody that are able to arouse nationalism and patriotism, which is a statement based on Pancasila and the 1945 Constitution. First, the melody is created with a simple pattern so that all Indonesian people can start singing from children to adults. Second, the lyric uses Indonesian language so that it can be understood by all Indonesian people. Third, patriotic songs are also called a monumental work because it was created based on events and recognized by the community and government, so that songwriters received awards as national heroes like W.R. Supratman who created the song "Kebangsaan Indonesia Raya" and Cornel Simandjuntak created many patriotic songs.

\section{OBJECTIVES}

This study aims to identify functions and meanings of patriotic songs as part of the preservation and character education system so that young generation can understand what nationalism and patriotism mean through melodies and lyrics. The substance described certainly has a moral and relevant message for all the time, not getting faded. The more often the song is played, the longer the compassion and the desire to apply the values in the song which then can give more hope. The current solution is how to fight poverty and backwardness. the songs function as a resistance to injustice such as corruption, radicalism and drugs as enemies of the nation at this time.

${ }^{1}$ T.W. Allen. "Hymn", in Stanley Sadie, ed., The New Grove Dictionary of Music and
The problems encountered today are that the values contained in the song struggle have obstacles and challenges due to changing times. The development of music is now more dominant towards pop music, so the patriotic songs should be developed by emphasizing character education and be taught in public schools.

\section{LITERATURE REVIEW}

The author examined previous studies on patriotic songs. It was discovered that the younger generation mostly did not understand the meaning of the song. As a matter of fact, song functions not only as a means of educating national character, but also building national vigilance, work ethics and the spirit of national discipline in facing global competition.

Literature review contains supporting information obtained from the literature and arranged systematically as follows.

T.W Allen (1980) 'Hymn' in The New Grove Dictionary of Music and Musicians. Volume 8, B. Stanley Sadie (ed.), Hymn was a song to honor and praise gods, heroes or prominent leaders. Hymns were presented as a sign of peace or a statement of thanks to the god of Apollo. After the classical period, hymns were used in the context of Christian liturgy. Hymn was defined as a prayer of the Christian church service in the eastern church rite. The nature of the hymn was combining melody with beautiful lyric. The text of the song lyrics was generally in the form of poetry using the Doriant technique, one tone per syllable, for example the song " Homeric Hymns", which was highly influenced by classical poetry. ${ }^{1}$

Musicians. Volume 8. (London: Macmillan Publisher, 1980), p. 836. 
Erick Schwandt \& Andrew Lamb (1980) "March" in The New Grove Dictionary of Music and Musicians Volume 11, Stanley Sadie (ed.), states that march is music with a fast rhythm to accompany and lift the spirits of troops with simultaneous movements in neat military processions. Songs were generally sung by troops trained in preparing themselves to fight on the front lines. The history of the German military march was first created by Virgil in 1820 entitled 'Aneid', aimed at arousing the spirit of the troops to accompany the forward movement of the troops in battlefields. March music is an ornamentation of drum rhythms in a fast tempo with accent movements developed in phrases with major keys. In the French revolution, under the rule of Napoleon Bonaparte (1789-1814), there were special songs for military march which gave French composers an opportunity to express sentiments towards enemies. The most famous composers were J. P.A Francois Devienne, Joseph Lifebure, and F.R. Gebauer, who composed patriotic march songs. ${ }^{2}$

\section{RESEARCH METHODS}

A number of qualitative data were collected from the beginning of the research until the process of writing of this research. Qualitative data analysis needed data selection according to the needs. Subsequently, critical explanation was carried out for all the information collected. furthermore, writing was done in stages based on accountable opinions and analytical abilities of the researcher. The qualitative research method has various sources below.

\section{WRITTEN SOURCES}

The value of written sources lies in the closeness of the relationship with some of the events recorded by the sources. Therefore, a researcher always uses primary resources, namely written sources that are closely related to national events where books and historical documents were written and then stored in national archives, R.R.I, museums and libraries in Jakarta, Bandung, Yogyakarta, Surabaya. Collecting data using printed written sources is known as library research. The sources include (1) Books, (2) Journal, (3) Encyclopedias (4) Brochures, (5)

${ }^{2}$ Erich Schwandt, Andrew Lamb "Marc", in Stanley Sadie, ed., The New Grove Dictionary of Music and Musician. Volume 11. (London: Macmillan Publisher, 1980), p. 650.
Magazines and newspapers, (6). Securities, archives and documents. ${ }^{3}$

\section{ORAL SOURCES}

Oral sources were collected through field research. Information from resource persons is useful, especially from historical witnesses who are still alive. Interviews with families of Kusbini's children and the late $I b u$ Sud were conducted openly (non-structured). The interviewees were allowed to tell without being interrupted. It could also be done with control (structured) that only for certain information was needed from the resource persons.

\section{DISCUSSION}

\section{"Bagimu Neg'ri" Built Pre-independence Nationalism (1908-1945)}

According to Ki Suratman who taught at Taman Dewasa Yogyakarta in 1943-1944, at that time Japan still banned the National Anthem 'Indonesia Raya' reverberating anywhere. Therefore, "Bagimu Neg'ri" was played as a substitute for the national anthem. ${ }^{4}$ After not functioning again as the substitute for the national anthem, in 1946-1947 "Bagimu Neg'ri" was used to accompany handover, promotion and inauguration ceremonies of Navy soldiers in Lawang, East Java. In 1948, Sukarno at the committee meeting of the National Anthem "Indonesia Raya" in Yogyakarta, proposed that "Bagimu Neg'ri" should also be considered to be adopted as the national anthem. Finally, such proposal was decided at the national anthem committee meeting that Bagimu Neg'ri was stipulated as the second national compulsory song to after the National Anthem "Indonesia Raya".

In 1959, "Bagimu Neg'ri" was designated as a national compulsory song for elementary school to higher education level, especially when accompanying the graduation ceremony while the audience was asked to stand. "Bagimu Neg'ri" had been used for a long time a closing song for news broadcast by Radio of the Republic of Indonesia (RRI) and national broadcast by Television of Republic of Indonesia TVRI. On August 30, 1979, "Bagimu Neg'ri" was first used in accompanying the signing ceremony and symbolic awards of Prasamya Purna Nugraha by President Suharto to

${ }^{3}$ R.M. Soedarsono. Metodologi Seni pertunjukan dan Seni Rupa (Bandung: Masyarakat Seni Pertunjukan Indonesia, 2001), p. 128.

${ }^{4}$ Kamajaya. Sejarah Bagimu Neg'ri Lagu Nasional (Yogyakarta: U.P. Nasional, 1979),46. 
Supardjo Rustam, the Governor of Central Java Province, in Semarang. On July 22, 2001 "Bagimu Neg'ri" accompanied the signing of the Presidential handover ceremony at the Special Session from the Chairman of the People's Consultative Assembly Amin Rais to the President of the Republic of Indonesia Megawati Sukarnoputri, from Vice President to be President of the Republic of Indonesia, accompanied by the Music Corps of Army Headquarters at the Building of the People's Consultative Assembly, Jakarta. ${ }^{5}$

\section{Bagimu Neg'ri}

Padamu Negri kami berjanji

Padamu Negri kami berbakti

Padamu Negri kami mengabdi

Bagimu Negri jiwa raga kami

\section{"MajuTak Gentar" Built Post-Independence Patriotism (1945-1949)}

In 1946 during the emergency status of the country, Sukarno and Mohammad Hatta moved the government to Yogyakarta. Along with a group led by Usmar Ismail, Cornel Simandjuntak also moved to Yogyakarta. Since then, Alumni of Hollands Inlandsche Kweekschool (HIK) Muntilan, in which Cornel Simandjuntak studied music, established a choir association named Pemuda Nusantara, specifically sang his composition which were routinely broadcast by RRI Kotabaru of Yogyakarta. The establishment of a choir that specifically sang patriotic songs through radio in 1946 made "Maju tak gentar" famous in the Yogyakarta Student Troop front. According to Franz Seda and Alex Rumambi, "Maju tak gentar" was able to ignite the fighting spirit of the fighters on the battlefield. ${ }^{6}$

On October 5, 2000, this song served as a song accompanying ceremony participants entering the ceremony field in order to celebrate the 55th Anniversary of Indonesian Military in the north square of the Yogyakarta Palace. On March 6, 2001, this song was played in the 40th Anniversary of Strategic Command of the National Army in Jakarta. On August 17, 2018, it was sung at the Yogyakarta Presidential Palace while the parade of ceremony participants entered the venue.

\footnotetext{
${ }^{5}$ Wisnu Mintargo, "Fungsi Lagu Perjuangan Indonesia Dalam Konteks Kemerdekaan Tahun 1945-1949” (Master Thesis, Universitas Gadjah Mada, Yogyakarta,2001)
}

\section{Maju Tak Gentar}

Maju tak gentar membela yang benar

Maju tak gentar hak kita diserang

Maju serentak mengusir penyerang

Maju serentak tentu kita menang

Bergerak-bergerak serentak-serentak

Menyerang menerkam terjang

Tak gentar tak gentar menyerang-menyerang

Majulah majulah menang

\section{CONCLUSION}

It can be concluded as a statement that patriotic songs apply all the time and for all groups. This is because, first, patriotic songs in public schools used in ceremonies to welcome national holidays; second, these songs are easy to memorize and close to the people, which contain constructive messages and suggestions as follows.

1. The primary function of the song "Bagimu Neg'ri" has a magnet as a ceremonial means, or known as a Magnetic Song. This song is delivered with solemn and profound feeling in slow tempo. It contains a strong appeal, so that we can make ourselves aware of being a united nation. Its appeal is like a strong magnet, not infrequently people who sing the song can shed tears because of emotional feelings and pride of the majesty of this song. "Bagimu Neg'ri" until now is sung by students as a closing song of learning activities in public schools and college graduation ceremonies throughout Indonesia.

2. The secondary function of the song "Maju Tak Gentar" to arouse the spirit of solidarity of a nation that loves the country against injustice. This song is played to accompany the procession the marching formation towards the battlefield. "Maju No Gentar" is called a Rhetoric Song which is performed with enthusiasm in fast tempo and contains messages and suggestions, as if a speech that is sung. "Maju No Gentar" was born from a period of warfare, of which spirit can reappear in the midst of society one day because of its characteristics and function to guard the country if the country receives internal and external threat during a social crisis. This song is played to unify determination, steps, sound and attitudes to represent the people of Indonesia.

${ }^{6}$ Teo Sunu Widodo interviewed with Franz Seda and Alex Rumambi written the brochure "Mengenang Cornel Simandjuntak", (Yogyakarta: Gedung Pertunjukan Societed, 29 September 1994), 4. 
Historically, it is already evident in the reform era that it was used a tool of criticism that succeeded in overthrowing the New Order regime with its corruption, collusion and nepotism in 1998. Currently, the song functions as a tool of criticism sung by students so that their aspirations are heard by the government. "Maju No Gentar" currently serves as the song of the military parade in accompanying the procession when participants enter the venue of the commemoration of the Anniversary of the Republic of Indonesia every August 17 at the Presidential Palace in Jakarta.

\section{Suggestions}

1. It is expected that the government pays a great deal of attention to the preservation of patriotic songs. The existence of choirs and patriotic songs is now increasingly less competitive with commercial songs that are packaged in CDs or DVDs.

2. The government should immediately make an official circular letter to civil and military institutions, and private companies, public schools to universities to re-popularize patriotic songs in order to increase national and state awareness in building nationalism and patriotism.

3. It is recommended that every time patriotic songs be played before activities in civil and military institutions, schools, university campuses, television, radio, theater, museums, and public places such as train stations, malls, inter-region bus stations and mainly in borders in the outermost islands of the Republic of Indonesia.

\section{BIBLIOGRAPHY}

Allen, T.W.. "Hymn", in Stanley Sadie, ed.,(1980) (The New Grove Dictionary of Music and Musicians. Volume 8. (London: Macmillan Publisher)

Kamajaya. (1979) Sejarah Bagimu Neg'ri Lagu Nasional (Yogyakarta: U.P. Nasional).

Mintargo, Wisnu.'Fungsi Lagu Perjuangan Indonesia Dalam Konteks Kemerdekaan Tahun 1945-1949” (Master Tesis, Universitas Gadjah Mada, Yogyakarta, 2001)

Schwandt,Erich. Andrew Lamb.(1980) "Marc", in Stanley Sadie, ed., The New Grove Dictionary of Music and Musician. Volume 11. (London: Macmillan Publisher).

Supriatun (2008).Karya Seni Monumental/Karya Seni Pertunjukan (Jakarta: Depdikbud)

Soedarsono,.R.M. (2001) Metodologi Seni pertunjukan dan Seni Rupa (Bandung: Masyarakat Seni Pertunjukan Indonesia).

Teo Sunu Widodo interviewed with Franz Seda and Alex Rumambi written the brochure "Mengenang Cornel Simandjuntak", (Yogyakarta: Gedung Pertunjukan Societed, 29 September 1994 